\title{
Pests and Pathogens of Trees and Shrubs Spreading in the North-Eastern Part of the Greater Caucasus (Azerbaijan)
}

\author{
K.A. Mammadova* \\ Azerbaijan State Pedagogical University, Azerbaijan \\ *Corresponding author
}

\begin{tabular}{|l|}
\hline Ke y w or d s \\
$\begin{array}{l}\text { Forest, Shrub, Tree, } \\
\text { Pests, Pathogens }\end{array}$ \\
\hline Article Info \\
\hline $\begin{array}{l}\text { Accepted: } \\
\text { 04 February } 2019 \\
\text { Available Online: } \\
\text { 10 March } 2019\end{array}$ \\
\hline
\end{tabular}

\section{A B S T R A C T}

İn 2015-2017 years has been studied influence of various pests and pathogens in the conditions of in situ and ex situ to the trees and shrubs spreaded in the studied area, identified their species composition and morphological characteristics. It was determined that some widely spread pests are damaging many types of plant. Such pests was relates silkworm (Ocneria dispar L.), maple mealybug (Phenacoccus aceris Sign.), false acacia (Parthenolecanium corni Bouche.), Oyster-shell scale (Quadraspidiotus ostreaeformis Curt.), San Jose scale (Quadraspidiotus perniciosus Comst.). Chionaspis salicis L., Quadraspidiotus pyri Licht., Operophthera brumata L. includes to the pests that most widely spread on the studied plants. The same pest that spreads on the many species of plants is affected by varying degrees, ühich becomes it more dangerous for some plants. As a result of the observations, became clear that, Phyllaphis fagi L., Cryptococcus fagisuga Lndgr. spread on the eastern pistachio, Unaspis evonymi Comst. spread on the European guelder rose are damaged only the species of one genus. During research was found widely spread pathogenic fungi on the studied trees and shrub plants. Pathogenic fungi such as Fomes fomentarius Gill., Inonotus obliquus (Pers.) Pil., Oxyporus populinus (Fr.) Donk. causes disease in many plant species. These pathogenic microorganisms causes white, brown, and velvety decay on the studies trees and shrubs. The results of the researchers was show that the pests in the conditions of in situ on plants meets more. In the condition of in situ plants more undergo to the diseases of pathogenic fungi. This difference can be correlated with environmental factors and lack of agrotechnical service in the conditions of in situ.

\section{Introduction}

In modern times, protection plants from pests and pathogens is an independent field of science, fuctions in the direction of forest massifs, botanical gardens to determine of species composition of plant pests and pathogenic microflora and implement this measures against to them. The harmful effects of various pests, fungi and bacterial diseases to the growth and development of plants, mass forms of this effect is determine with their biological feature and cellular properties $(2,3,7,8)$. Although chemicals method are widely used for the protection of plants, biological, agro-technical, and preventive methods are also used in recent years. 
In the literature meets information about the pests and pathogens of some plants.

In Guba, Yalama forest massifs in Azerbaijan on the oak trees was spreaded pests as dust bandage(Portheria dispar L.), maryam worm (Nygma phaeodisca L.), green leaf butterfly(Tortrix viridana $L$. In the oak forests meets mazi insect that feeds with long stalk and Georgian oak leaves. Trunked insect of oak cones(Balaninus nucum, B.glandium) as one of the pest of oak cones in the widespread years was destroyed all oak cones productivity.

In the forest of oak also was spread pathogens by ash fungi (Microsphaera alphitoides Griffin et al.,) (1).

375 species of fungi were found on the forest forming genuses of trees in Azerbaijan (Fagus L., Quercus L., Carpinus L.) which 65 of them are pathogenic and causes diseases. On the Eastern beech were encountered 28 species belonging to the 15 genus of family Shpaeriodaceae, 80 species from the 31 genus on the oak, 12 species from the 7 genus on the Caucasian hornbeam(6).

Conidies of fungi(Microsphaera alphitoides Griff. et M.) causeing diseas ashes on oak spreaded in the Yalam, Guba, Devechi forests is germinat when the relative humidity of the air is $60-85 \%$, the temperature above 150 . The spread of fungi occurs in June-August in lessnutrient soils(5).

Durind study the bioecological properties of tinder fungus spread in the forests of SamurDavachi was noted that, more quantitie of fungi was observed on the live oak and hornbeam, less amount on the live Pytherocarpa. The live hawthorn bushes were very resistant to the impact of tinder fungus and not observed contagion with any fungi(2).
On the rarely and endangered woody plants in the ex situ condition was identified 35 species of pests and 31 species pathogens but in the condition of in situ was identified 39 species of pests and 36 species of pathogens. Last years warming of climate and increasing humidity in Absheron caused increasing the variety of pathogenic fungi in cultural conditions. It was determined that the role of widespread diseas creators and pests in ex situ conditions is not decisive in reducing the areal of studied plants (7).

Goal of research was to study the influence of pests and pathogens to the trees and shrubsin in the conditions of in situ and ex situ, determined their species composition and choose resistants species of trees and shrubs to these impacts and to use them in greenery.

\section{Materials and Methods}

The study was carried out on the trees and shrubs on the forests of north-eastern part of the Greater Caucasus and as well as on the trees and shrub plants introduced to the research area of Central Botanical Garden of ANAS.

In researches for the identifield pest was used specile methods, for the identification of microorganizms and diseace caused by them were used according determinations $(11,10)$.

\section{Results and Discussion}

As a result of research was identified species composition of pest and pathogens in condition of ex situ and in situ of studied plants. Obtained results was shown in Table 1. It has been established that some pests are widely spread and damage many species of plant species. Some pest such as field silkworm (Ocneria dispar L.), maple mealybug (Phenacoccus aceris Sign.), false acacia (Parthenolecanium corni Bouche.), 
Oyster-shell scale (Quadraspidiotus ostreaeformis Curt.), San Jose scale (Quadraspidiotus perniciosus Comst.) meets on the trunk, branches and leaves and causes to the drying trunk and falling leaves. These pests are found in plants end of May, early June.

\section{Ocneria dispar $L$.}

Male of this butterfly in open form is $5 \mathrm{~cm}$ in size and dark colored. The female is $7 \mathrm{~cm}$ in size, white, with black dots on his wings. Early spring when the shoots of trees are opened caterpillars getting out of the eggs are fed by buds, flowers and leaves. Caterpillars are covered with hairs. The caterpillars have 3 thin yellowish lines on the back, the first 5 joint are blue-colored and in the nexts meets red-colored warts.

\section{Phenacoccus aceris Sign}

Male and female pests are found in shoot, branches, trunks and leaves. The body of the mature female is covered with powdery, rounded, greenish - yellow, length is $4 \mathrm{~mm}$, width is $2 \mathrm{~mm}$. Larvae are wintering under the shells of the trunk and branches, in summer months grows on leafs, green woody shoots.

\section{Parthenolecanium corni Bouch}

Larvas and females are spread on thin branches, leaves, rarely in thick branches, in the trunks. Females are round, dark-yellow or red-brown, bright, with a length of $3,5 \mathrm{~mm}$. Mass formation occurs at the end of May, early June. It is dangerous for many breeds.

\section{Quadraspidiotus ost reaeformis Curt}

The larvae and the females are damaging in the trunks, branches and shoots and causing them to dry. The shield of the females is round, 2-2,3 $\mathrm{mm}$ in diameter, the center part is olive-gray, the edges are light-colored. At the end of May, early June, they puts eggs.

As seen from the table Chionaspis salicis L., Quadraspidiotus pyri Licht., Operophthera brumata $L$. relates to the pests widely spread on the studied plants.

\section{Quadraspidiotus pyri Licht}

Larvas and females are found in the trunks and branches. From the effects of pest, the bark of plants gradually is crumbles, branches, even whole plant dries up. The shield of the famales is dark-gray, roundly, $2,5 \mathrm{~mm}$ in diameter. İt is one of the dangerous pest.

\section{Operophthera brumata $L$}

This is a pest end of April, early May when the leaf forms on plants they formed from eggs laid on the shell of the internode of trees. Caterpillars are smooth, dark-green, brownheaded, dark red-brown in the back section, 3 white or yellowish stripes from the side.

\section{Chionaspis salicis $L$}

Larvas and females are damaging the branches. Pest covers trunks and branches in the form of bark. Dried out branches, prevents growth, even causing completely dry or destroy of plant.

The same pest that spreads on many species of plant and impacts to the plants with vary degrees becomes more dangerous for some plants. As a result of the observations became clear that, part of the pests, like as, Phyllaphis fagi L., Cryptococcus fagisuga Lndgr. spreaded on the eastern beech and Unaspis evonymi Comst spreaded on the European guelder rose are damaged only the species of one genus. 
Table.1 Pests and diseases of the studied plants

\begin{tabular}{|c|c|c|c|c|}
\hline № & Pests & $\begin{array}{l}\text { Plant species which were observed pest on } \\
\text { them }\end{array}$ & Pathogens & $\begin{array}{l}\text { Plant species which were } \\
\text { observed pathogens on them }\end{array}$ \\
\hline 1. & Ocneria dispar $L$. & $\begin{array}{l}\text { Quercus iberica, Q. pedunculiflora, } \text { Fagus } \\
\text { orientalis, Carpinus caucasica, Betula } \\
\text { pendula, Ulmus carpinifolia, Tilia } \\
\text { begoniifolia, T.cordata, Fraxinus excelsior, } \\
\text { Populus hybrida, P.nigra, P. tremula. }\end{array}$ & $\begin{array}{l}\text { Microsphaera } \\
\text { alphitoides } \\
\text { Griff. et Maubl. }\end{array}$ & pedunculiflora, \\
\hline 2. & Operophthera brumata $L$. & $\begin{array}{l}\text { Fraxinus exselsior, Ulmus carpinifolia, U. } \\
\text { glabra, Quercus pedunculiflora, Tilia } \\
\text { begoniifolia, T.cordata. }\end{array}$ & Septoria carpinea Davis & Carpinus caucasica \\
\hline 3. & Malacosoma neustria L. & $\begin{array}{l}\text { Ulmus carpinifolia, U.glabra, Quercus } \\
\text { iberica, Q.pedunculiflora, Corylus avellana }\end{array}$ & aqi $W r$. & Fagus orientalis \\
\hline 4. & Phenacoccus aceris Sign. & $\begin{array}{l}\text { Quercus pedunculiflora, Q.iberica, Betula } \\
\text { pendula, B.raddeana, Alnus incana, Populus } \\
\text { hybrida, P. tremula Carpinus caucasica, } \\
\text { Lonicera xylosteum, L.caucasica, Acer } \\
\text { campestre, A.laetum, A.platanoides, } \\
\text { Crataegus curvisepala, C.pentagyna }\end{array}$ & $\begin{array}{l}\text { Oxyporus } \quad \text { populinus } \\
\text { (Fr.) Donk. }\end{array}$ & $\begin{array}{l}\text { Fraxinus excelsior, Alnus } \\
\text { incana, Ulmus carpinifolia, } \\
\text { U.glabra, Betula pendula, Acer } \\
\text { campestre, Acer velutinum, A. } \\
\text { Trautvetteri. Sorbus caucasica, } \\
\text { Quercus pedunculiflora }\end{array}$ \\
\hline 5. & $\begin{array}{l}\text { Parthenolecanium persicae } \\
F .\end{array}$ & $\begin{array}{l}\text { Corylus avellana, Fraxinus excelsior, Acer } \\
\text { velutinum, A.campestre, A.laetum }\end{array}$ & ymus mosaic & Euonymus europaea \\
\hline 6. & $\begin{array}{l}\text { Parthenolecanium rufulum } \\
\text { Ckll. }\end{array}$ & $\begin{array}{l}\text { Carpinus caucasica, Corylus avellana, } \\
\text { Quercus pedunculiflora }\end{array}$ & $\begin{array}{l}\text { Ascochyta quercus Sacc. } \\
\text { et Speg. }\end{array}$ & $\begin{array}{l}\text { Quercus iberica, Q.peduncu- } \\
\text { liflora }\end{array}$ \\
\hline 7. & Chionaspis salicis L. & $\begin{array}{l}\text { Alnus incana, A.barbata, Fraxinus excelsior, } \\
\text { Acer campestre, A. trautvetteri, Populus } \\
\text { hybrida, P.nigra, P. tremula, Tilia } \\
\text { begoniifolia }\end{array}$ & $\begin{array}{l}\text { Inonotus } \\
\text { (Pers.) Pil. }\end{array}$ & $\begin{array}{lr}\text { Alnus incana, Fagus } & \text { orientalis, } \\
\text { Ulmus glabra, } & \text { Quercus } \\
\text { pedunculiflora, } & \text { Populus } \\
\text { hybrida } & \end{array}$ \\
\hline 8. & Eriocampa ovata $L$. & Alnus barbata, A.incana & $\begin{array}{l}\text { Pseudomonas quercus } \\
\text { Schem. }\end{array}$ & $\begin{array}{l}\text { Quercus iberica, Q.peduncu- } \\
\text { liflora }\end{array}$ \\
\hline 9. & $\begin{array}{l}\text { Parthenolecanium } \\
\text { Bouche. }\end{array}$ & $\begin{array}{l}\text { Carpinus caucasica, Alnus incana, Betula } \\
\text { pendula, Fagus orientalis, Corylus avellana, }\end{array}$ & Fomes fomentarius Gill. & $\begin{array}{l}\text { Betula pendula, } \\
\text { excelsior, } \quad \text { Populus }\end{array}$ \\
\hline
\end{tabular}




\begin{tabular}{|c|c|c|c|c|}
\hline & & $\begin{array}{l}\text { Acer laetum, A. campeste, Quercus } \\
\text { peduncuflora, Fraxinus excelsior, Lonicera } \\
\text { xylosteum, Populus hybrida, P.nigra, P. } \\
\text { tremula, Ligustrun vulgare, Crataegus } \\
\text { pentagyna, Euony-mus europaea, E.latifolia }\end{array}$ & & $\begin{array}{l}\text { P.hybrida, Quercus pedun- } \\
\text { culiflora, Fagus orientalis, } \\
\text { Carpinus caucasica, Almus } \\
\text { incana, Tilia begoniifolia, } \\
\text { T.cordata, Salix arbuscula }\end{array}$ \\
\hline 10. & Agrilus angustulus Tll. & Quercus pedunculiflora, Q.iberica & Polyporus hispidus F. & Fraxinus excelsior \\
\hline 11. & Phyllaphis fagi $L$. & Fagus orientalis & $\begin{array}{l}\text { Cytospora decorticans } \\
\text { Sacc. }\end{array}$ & Carpinus caucasica \\
\hline 12. & Targionia vitis Sign. & $\begin{array}{l}\text { Fagus orientalis, Quercus pedunculiflora, } \\
\text { Q.iberica }\end{array}$ & $\begin{array}{l}\text { Phyllosticta agrifolia } \\
\text { Ell. et ev. }\end{array}$ & Fagus orientalis \\
\hline 13. & Unaspis evonymi Comst. & Euonymus europaea & $\begin{array}{l}\text { Cytospora quercella } \\
\text { Brum. }\end{array}$ & Quercus macranthera \\
\hline 14. & Quadraspidiotus pyri Licht. & $\begin{array}{l}\text { Carpinus caucasica, Crataegus pentagyna, } \\
\text { Fraxinus excelsior, Malus orientalis, Pyrus } \\
\text { caucasica }\end{array}$ & $\begin{array}{l}\text { Inonotus } \quad \text { hispidus } \\
\text { (Bull.ex.Fr.) }\end{array}$ & Fraxinus excelsior \\
\hline 15. & Tortrix viridana $L$. & $\begin{array}{l}\text { Tilia begoniifolia, Quercus peduncu-liflora, } \\
\text { Acer campestre, A.laetum }\end{array}$ & $\begin{array}{l}\text { Phyllactinia } \quad \text { suffulta } \\
\text { Sacc. }\end{array}$ & $\begin{array}{l}\text { Pterocarya pterocarpa. } \\
\text { Fraxinus excelsior, Loni-cera } \\
\text { xylosteum L.caucasica }\end{array}$ \\
\hline 16. & $\begin{array}{l}\text { Quadraspidiotus } \\
\text { ostreaeformis Curt. }\end{array}$ & $\begin{array}{l}\text { Corylus avellana, Acer campestre, Grataegus } \\
\text { pentagyna, Pyrus caucasica, Populus } \\
\text { tremula }\end{array}$ & Uncinula aceris Sacc. & Acer laetum, A.campestre \\
\hline 17. & $\begin{array}{l}\text { Cryptococcus fagisuga } \\
\text { Lndgr. }\end{array}$ & Fagus orientalis & $\begin{array}{l}\text { Daedalea quercina (L.) } \\
\text { Fr. }\end{array}$ & $\begin{array}{l}\text { Quercus pedunculiflora, } \\
\text { Q.iberica }\end{array}$ \\
\hline 18. & $\begin{array}{l}\text { Quadraspidiotus gigas Th. et } \\
\text { Gern. }\end{array}$ & $\begin{array}{l}\text { Alnus incana, Salix caucasica, Populus } \\
\text { tremula, P.alba }\end{array}$ & $\begin{array}{l}\text { Phyllosticta quercus } \\
\text { Sacc.et Speg. }\end{array}$ & Quercus iberica \\
\hline 19. & $\begin{array}{l}\text { Quadraspidiotus perniciosus } \\
\text { Comst. }\end{array}$ & $\begin{array}{l}\text { Euonymus europaea, Betula pendula, } \\
\text { Ligustrum vulgare, Fraxinus excelsior, Pyrus } \\
\text { caucasica, Acer laetum, A.campestre, } \\
\begin{array}{l}\text { A.velutinum, Populus hybrida, Populus } \\
\text { tremula }\end{array}\end{array}$ & Phoma hariotiana Wint. & Fagus orientalis \\
\hline
\end{tabular}




\section{Phyllaphis fagi L}

Folding leaves of eastern beech in the lower part gets covered with long white waxly hair. In summer, in June are form wingless females, winged men, in August, their numbers speedily droppes, in September form again.

\section{Cryptococcus fagisuga Lndgr.}

Larvae and females forming a thick colony on the trunk of the eastern beech damage it. The female are very small, $1 \mathrm{~mm}$ in diameter, yellow, covered white pile of wax. They put eggs in July.

\section{Unaspis evonymi Comst}

The larvae and females of this pest are living on the European guelder rose causing great damage to the trunks and leaves. Causes loss leaves and drying of the plant. The shield of female is dark-brown, rough and visible robust. The shield of male is white, lengthy with 2 holes.

During carried out of research was found widely spread pathogenic fungi on the studied trees and shrubs. These fungus damage trunks, branches, leaves, and cause the plant to death. Pathogenic fungi such as Fomes fomentarius Gill., Inonotus obliquus (Pers.) Pil., Oxyporus populinus (Fr.) Donk. causes disease in many species of plant. These pathogenic microorganisms causes white, brown, and velvety decay on the studies trees and shrubs.

The results of the carried out of researchers was show that the pests in the conditions of in situ on plants meets more. In the condition of in situ plants more undergo to the diseases of pathogenic fungi. This difference can be correlated with environmental factors and lack of agrotechnical service in the conditions of in situ.
According to the results of the study the pests damage the weakly developed plants. Due to lack of agrotechnical service in the natural environment, some plants are left out of development and are damaged by pests.

Some of the investigated species of trees and shrubs more resistant to the effects of pests and pathogens.

The studied tree and shrubs may be widely used on greening.

\section{References}

1. Bandin A.P. 1954. Oak forests of the Azerbaijan SSR, Baku, Azerbaijan SSR EA, 158

2. Ganbarov Kh.G., Kerimov V.M. 2011. Eco-biological characteristics of bazidial fungi causing wooden decay spreaded in the Samur-Davachi lowland forests, 128

3. Pests and diseases of field-protective forest plantations and their control. 1951. M.-L. State Ed. Agricultural. Literature, 324.

4. Pests of forest. 1955. M.; L. Ed. AN USSR. 1-2:421.

5. Guseynov E.S. 1985. Conditions for the development of powdery mildew of oak in Azerbaijan. News of the Academy of Sciences of Azerbaijan. SSR, series of biological sciences, 3:124-127

6. Guseynov E.S. 1987. Pycnidial fungi of the main forest-forming species of Azerbaijan.News of the Academy of Sciences of Azerbaijan. SSR, series of biological sciences, 1:94-100.

7. İskender E.O., Khaciyeva S.A. Gakhramanova A.Y. 2009. Pests and pathogens of rare and endangered woody plants of Azerbaijan under ex situ and in situ conditions. Scientific works:İnstitute of Microbiology of the NASA, 7:206216.

8. Korchagin V.A. Protect the garden from 
pests and diseases. 1978. M.: Kolos, 284.

9. Sinadshkiy Y.V., Korneeva İ.T., Dobrochinskaya İ.B. and oth. 1987. Pests and diseases of flower-decorative plants., M. "Science", 592.
10. Khokhryakov M.K., Dobrozrakova T.L., Stepanov K.M.. Letova M.F. 2003. The determinant of plant diseases. SPB., 592/http:||www. agroatlas. spb.ru

\section{How to cite this article:}

Mammadova, K.A. 2019. Pests and Pathogens of Trees and Shrubs Spreading in the NorthEastern Part of the Greater Caucasus (Azerbaijan). Int.J.Curr.Microbiol.App.Sci. 8(03): 330336. doi: https://doi.org/10.20546/ijcmas.2019.803.041 